\title{
Lahnda Language
}

National Cancer Institute

\section{Source}

National Cancer Institute. Lahnda Language. NCI Thesaurus. Code C153995.

A group of north-western Indo-Aryan language varieties spoken in Pakistani Punjab and in parts of the neighboring Azad Kashmir and Khyber Pakhtunkhwa. 